\title{
Fajr 2003
}

\author{
By Gönül Dönmez-Colin
}

Fall 2003 Issue of KINEMA

\section{THE $21^{\text {st }}$ FAJR INTERNATIONAL FILM FESTIVAL}

(1-11 February 2003) offered twenty-two films in the Competition section, three of which were from Iran. Reza Mir-Karimi's Here, a Shining Light explored the issue of religious faith in the story of the custodian of a shrine who looks for a replacement when he is obliged to go to town for medical treatment. Villagers who have lost faith in the shrine offer no help, which forces him to turn over the responsibility of the shrine to his mentally retarded son with unexpected consequences. Vahid Mousayian's second feature, Silence of the Sea was a poetic rendition of the inner turmoil of an exile trying to connect his severed ties with his roots. Asghar Farhadi's Dance in the Dust also delved into the theme of loneliness of the uprooted although the protagonist of his film was a simple Azari youth rather than an intellectual doctor as in the Silence.

Among other competition entries, Büyük Adam. Küçük Aşk / Big Man Little Love (2001) by Handan Ipekci from Turkey focused on the human dimensions of ethnical relationships. Incidentally, this film was banned in Turkey just before the Istanbul International Film Festival after having won awards at Ankara and Antalya Film Festivals and having enjoyed a successful commercial release. Ticket to Jerusalem (2002) by Palestinian Rashid Masharawi and Divine Intervention by Elia Suleiman drew attention to the daily lives of Palestinians, often eschewed by CNN reports. From the US, the notorious Michael Moore's very popular documentary (at least on this side of the Atlantic), Bowling for Columbine gave a humorous insider's view of America through its gun control laws.

While these films were screened in theatres around the city for the benefit of the local public, the foreign guests followed a separate program of four new Iranian films each day at the cineclub of the Museum of Contemporary Arts. Organised by the Farabi Cinema Foundation, these screenings ran parallel to the $6^{\text {th }}$ Iranian Film Market with its several stands arranged in the lobby of the Laleh Hotel (the Inter-Continental of the old regime) welcoming foreign guests. Under the direction of Mr. Amir Esfandiari, who is the director of the Farabi Cinema Foundation, the market was an excellent venue to screen videos or to chat with colleagues until past midnight.

Majority of the directors competing in the national section were either making their debut or presenting their second projects. There seems to be a remarkable motivation among the youth to enter the field of cinema and this was manifest on countless occasions when male or female young film students approached the foreign delegates to ask for critical opinion of their films. Another endorsement of new blood coming to Iranian cinema was that the first films competition included no less than fifteen long feature films.

Letters of the Wind by Alireza Amini depicted a sensitive young man's entry to the male culture of the army through clever use of his creativity. Putting his walkman to collective use, the hero recorded conversations on his leave (especially of girls with a nice voice) and played these in the evening to the lonely soldiers. He also recorded their messages to transmit to relatives by phone. A clever comedy on army life, or an allegory on art overcoming restrictions? The first could hardly camouflage the second.

The motif of the refugee has been a strong subject in recent Iranian films. Considering the country's strategic location regarding current political upheavals, this is no surprise. Insightful works such as Majid Majidi's Baran and Abolfazl Jalili's Delbaran have already exposed the plight of refugees and drawn attention to the predicaments of Iranians faced with situations beyond their control. Paradise is Somewhere Else! by Abdolrassul Golbon was about the unfortunate youngsters who were lost between borders. The film used visual means effectively to accentuate the underlying theme.

A novelty for Iranian cinema is the motorcycle film, which often reflects youth going through an existential crisis. Deep Breath by Parviz Shahbazi was one such film that explored the anxieties of young people in a period of transition from tradition to modernity. 
A favourite among foreign guests was Gogouman / Twilight by Mohammad Rasulof, based on a true story of a couple who were married in prison as part of a rehabilitation experiment. Their life out of jail proved to be no less hostile than that behind the bars, which led to the inevitable ending. Rasulof deliberately avoided cheap melodrama or moralistic overtones and particularly, false optimism. Amazingly, he kept his sense of humour even under dire circumstances. One good example of the last was when the mother-in-law, who is also a prisoner, begins to treat her new daughter-in-law the way she would treat her if they were outsideordering her around, making her to wash her clothes, etc.

Interestingly, local critics and the public seemed to prefer a different film, The Mad Escaped the Cage by Mohammadreza Takht Keshiyan, with a plot that was incomprehensible to the foreign audience. The film garnered the prestigious Crystal Simorgh for Best Film.

Feminist filmmaker Tahmineh Milani's Fifth Reaction concluded the 'Feresteh trilogy', comprising Two Women and The Hidden Half, films with a heroine named Fereshteh (meaning angel in Farsi), always played by Niki Karimi. This film is another statement of her stance on the oppression of women in patriarchal societies. Five women teachers live lives of compromise arising from their secondary status as women. While four cope with their situations, the fifth woman, Feresteh reacts, hence the title of the film. Feresteh is practically thrown out of the authoritarian father-in-law's house when she refuses to marry her brother-inlaw after the death of her husband. She is also denied the custody of her children. Then begins a relentless chase across Iran. The father-in-law concedes when he knows he is losing the battle, however he has one condition. The last frame freezes as he points his finger at Fereshteh curled up in a corner of her prison cell.

Several short films and documentaries also competed for the Crystal Simorgh. A documentary by actress Yasamin Malek-Nasr, The Lost Truth focused on how ordinary people cope with daily realities in war-torn Afghanistan. Unlike CNN reports that relentlessly display starving children, which is humiliating to people who are already in difficult situations, Malek-Nasr's camera looks for stories of hope in women of the country working as doctors or teachers, trying to build their country. They serve as metaphors for culture, arts and poetry ignored by Western reporters. Lines from the great poet Rumi sum up their situation: 'I am a mirror, when I am broken, I am sharper.'

Special sections of the festival presented films from other festivals around the world and tributes to masters -Ozu, Chaplin, Kaurismäki and Mehrjui- to a very enthusiastic audience, which seemed to be thirsty for good cinema.

\section{References}

\section{AWARDS}

INTERNATIONAL COMPETITION

Crystal Simorgh Best Film:

The Son by Jean-Pierre and Luc Dardenne (Belgium)

Prize of the International Jury:

Dance in the Dust by Asghaar Farhadi (Iran)

Best Director:

Alex Moradev from Russia for The Kite

NATIONAL COMPETITION

Crystal Simorgh for Best Film

The Mad Escaped the Cage by Mohammadreza Takht Keshiyan

Special Jury Prize

Carpet of the Wind by Kamal Tabrizi 


\section{Best Director}

Reza Mir Karimi for Here, a Shining Light

\section{Best Actor}

Habib Rezaie in Here, a Shining Light

Best Actress

Niki Karimi in The Mad Escaped the Cage and The Fifth Reaction

\section{Author Information}

Gönül DÖNMEZ-COLIN is an independent researcher and writer whose publications include Women, Islam and Cinema, Cinemas of the Other: A personal Journey with Filmmakers from the Middle East and Central Asia, Cinema of North Africa and the Middle East (ed.); Turkish Cinema: Identity, Distance and Belonging (Reaktion Books), and Routledge Dictionary of Turkish Cinema (2014). 